\title{
Classical dynamin DNM1 and DNM3 genes attain maximum expression in the normal human central nervous system
}

\author{
Antoni Romeu* and Lluís Arola
}

\begin{abstract}
Dynamin is a super-family of large GTPase proteins that polymerise during their biological activity. Dynamin polymers form around lipid tubes and contribute to the membrane fission and scission of nascent vesicles from parent membranes. Here we used the NCBI Gene Expression Omnibus (GEO) database and the BioGPS gene expression portal to study differential dynamin gene expression in normal human organs or tissues. From the GDS1096 and GDS596 dataset, we downloaded the relative expression levels of dynamin-related genes (presented as percentages), with respect to all of the other genes on the array (platform Affymetrix GPL96), which includes the best characterised human genes. The expression profiles of dynamin in the central nervous system (CNS) are clearly distinct from the expression profiles in the other organs or tissues studied. We found that the classical dynamin DNM1 and DNM3 genes reach their maximum expression levels (100\% of maximal expression) in all normal human CNS tissues studied. This is in contrast to the expression profile in the other normal human organs or tissues studied, in which both dynamin DNM1 and DNM3 genes showed approximately 50\% maximal expression. This data mining analysis supports the concept that there is a relationship between the synapse and the molecular function of dynamin, suggesting a new field of work in the study of neurodegenerative diseases.
\end{abstract}

Keywords: Dynamin, Central nervous system, Gene expression, Data mining

\section{Discussion}

We have focused our attention on the expression profiling of dynamin genes in several normal human organs or tissues, using the NCBI Gene Expression Omnibus (GEO) database. We have chosen to study dynamin genes because dynamin is a super-family of GTP-binding mechanochemical proteins that are involved in fundamental processes, such as the scission of nascent vesicles from parent membranes and mitochondrial fusion and/or fission [1]. In addition, we believe that the dynamin super-family is a biological system suitable for studying differential gene expression in organs or tissues.

Specifically, we considered the group of genes coding the following protein families within the dynamin superfamily [2]: (i) the classical dynamins and dynamin-like proteins that tubulate and sever membranes and are involved in clathrin-mediated endocytosis and other vesicular trafficking

\footnotetext{
* Correspondence: antoni.romeu@urv.cat

Nutrigenomics Research Group, Department of Biochemistry and Biotechnology, Rovira i Virgili University, Tarragona, Spain
}

processes (DNM1, DNM1L, DNM2, DNM3); (ii) the guanylate-binding proteins, which are induced by type II interferons and anti-inflammatory cytokines (GBP1 and GBP2); (iii) the proteins on the outside of the outer mitochondrial membrane that participate in mitochondrial fusion and contribute to the maintenance and function of the mitochondrial network (MFN1 and MFN2); (iv) proteins in the mitochondrial inter membrane space that are involved in mitochondrial fusion, and in which mutations in the gene are associated with optic atrophy type 1 (OPA1); and $(v) \mathrm{Mx}$ proteins, which are involved in resistance against viral infections (MX1 and MX2). Taken together, these proteins constitute a large set of GTPase proteins that polymerise within each group or family according to the dynamin molecular function [3]. These dynamin polymers (such as rings and helices) are formed around lipid tubes and contribute to membrane fission [4].

To address this issue, we relied on the independent studies by Su A.I. et al. [5] (GDS596) and Ge X. et al. [6] (GDS1096). We downloaded the relative expression levels 


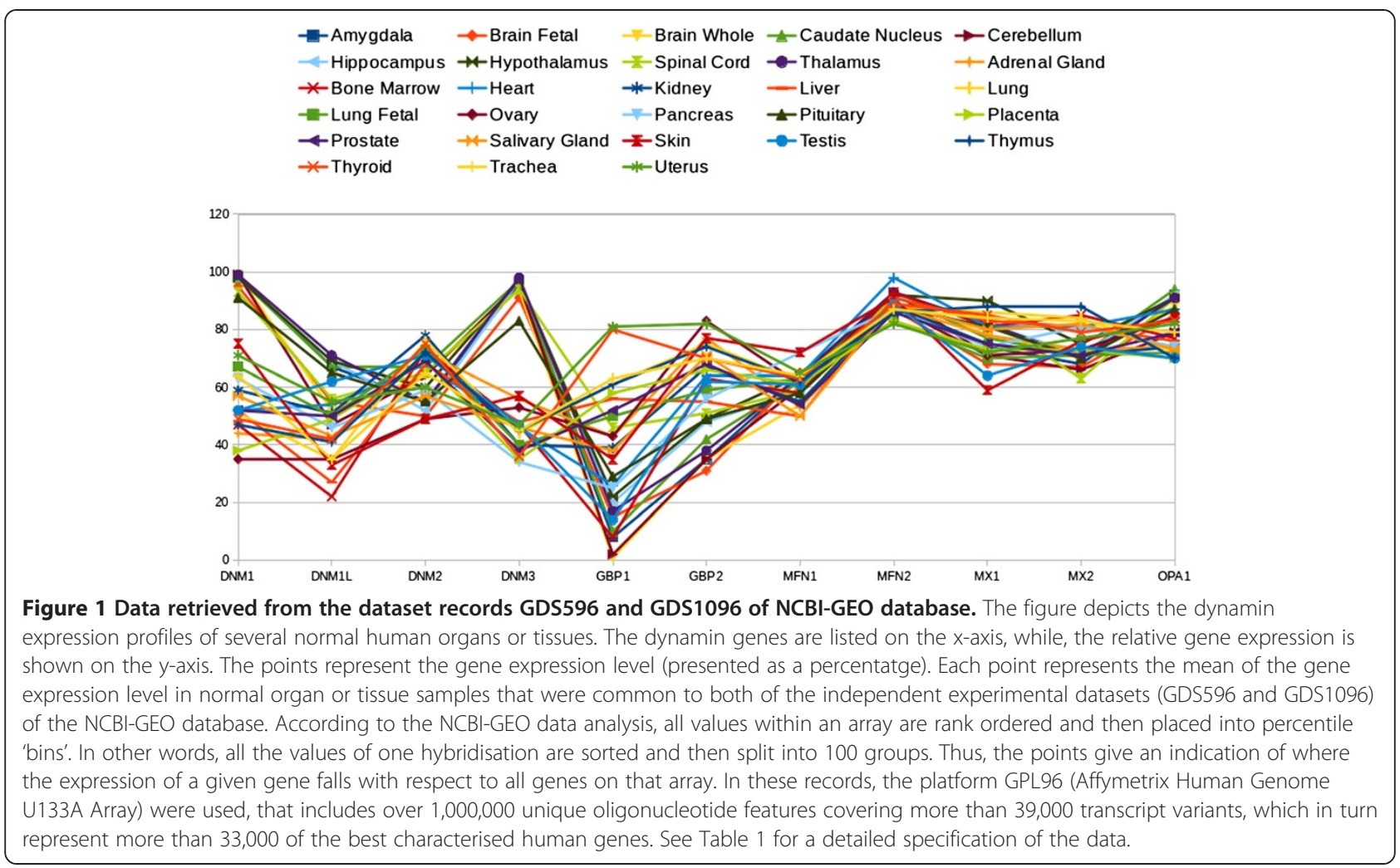

of dynamin-related genes (presented as percentages) with respect to all other genes on the array from these NCBIGEO database records. It is important to note that both NCBI-GEO data sets were created based on the same array platform (Affymetrix GPL96), which include all the best characterised human genes. Figure 1 shows the profiles of dynamin gene expression levels (expressed as percentage and presented as beam shaped lines) in samples from normal human organs or tissues that are common to the NCBI-GEO records of both studies. From a strict visual analysis of these beam lines, the data can be separated into two consistent populations or sub-beam lines of expression profiles, one of which groups together the profiles corresponding to components of the central

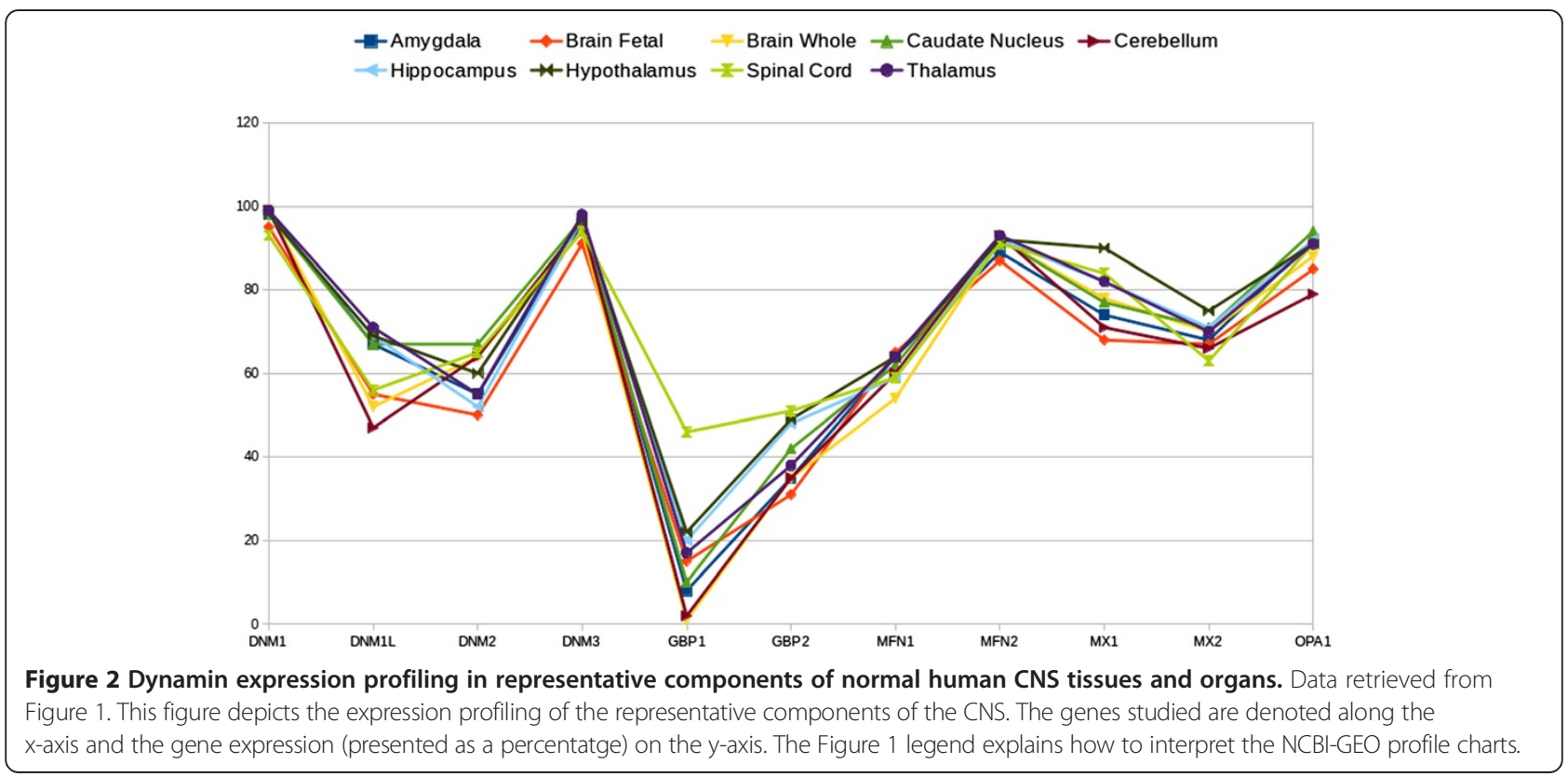


Table 1 Relative gene expression profiles from normal human organs and tissues (presented as percentatges)

\begin{tabular}{|c|c|c|c|c|c|c|c|c|c|c|c|}
\hline Organ-tissue & $\begin{array}{c}\text { DNM1 } \\
\text { (215116_s_at) }\end{array}$ & $\begin{array}{c}\text { DNM1L } \\
\text { (203105_s_at) }\end{array}$ & $\begin{array}{c}\text { DNM2 } \\
\text { (202253_s_at) }\end{array}$ & $\begin{array}{c}\text { DNM3 } \\
\text { (209839_at) }\end{array}$ & $\begin{array}{c}\text { GBP1 } \\
\text { (202269_x_at) }\end{array}$ & $\begin{array}{c}\text { GBP2 } \\
\text { (202748_at) }\end{array}$ & $\begin{array}{c}\text { MFN1 } \\
\text { (211801_x_at) }\end{array}$ & $\begin{array}{c}\text { MFN2 } \\
\text { (201155_s_at) }\end{array}$ & $\begin{array}{c}\text { MX1 } \\
\text { (202086_at) }\end{array}$ & $\begin{array}{c}\text { MX2 } \\
\text { (204994_at) }\end{array}$ & $\begin{array}{c}\text { OPA1 } \\
\text { (212213_x_at) }\end{array}$ \\
\hline Amygdala & 99 & 67 & 55 & 96 & 8 & 35 & 64 & 89 & 74 & 68 & 92 \\
\hline Brain foetal & 95 & 55 & 50 & 91 & 15 & 31 & 65 & 87 & 68 & 67 & 85 \\
\hline Brain whole & 99 & 52 & 64 & 94 & 1 & 35 & 54 & 92 & 78 & 70 & 88 \\
\hline Caudate nucleus & 98 & 67 & 67 & 97 & 10 & 42 & 62 & 92 & 77 & 71 & 94 \\
\hline Cerebellum & 99 & 47 & 64 & 96 & 2 & 35 & 60 & 93 & 71 & 66 & 79 \\
\hline Hippocampus & 98 & 69 & 52 & 97 & 20 & 48 & 59 & 92 & 82 & 71 & 92 \\
\hline Hypothalamus & 98 & 69 & 60 & 97 & 22 & 49 & 64 & 92 & 90 & 75 & 91 \\
\hline Spinal cord & 93 & 56 & 65 & 94 & 46 & 51 & 59 & 91 & 84 & 63 & 91 \\
\hline Thalamus & 99 & 71 & 55 & 98 & 17 & 38 & 64 & 93 & 82 & 70 & 91 \\
\hline Adrenal gland & 44 & 42 & 72 & 56 & 43 & 77 & 53 & 88 & 78 & 73 & 74 \\
\hline Bone marrow & 47 & 22 & 73 & 47 & 8 & 63 & 58 & 93 & 81 & 85 & 77 \\
\hline Heart & 52 & 54 & 68 & 46 & 26 & 64 & 64 & 98 & 81 & 81 & 87 \\
\hline Kidney & 59 & 51 & 78 & 40 & 39 & 67 & 55 & 88 & 75 & 71 & 74 \\
\hline Liver & 52 & 27 & 68 & 48 & 56 & 55 & 50 & 91 & 83 & 81 & 76 \\
\hline Lung & 51 & 35 & 76 & 44 & 61 & 75 & 62 & 88 & 86 & 84 & 72 \\
\hline Lung foetal & 67 & 50 & 73 & 40 & 50 & 59 & 63 & 83 & 70 & 71 & 72 \\
\hline Ovary & 35 & 35 & 49 & 53 & 43 & 83 & 61 & 88 & 71 & 73 & 84 \\
\hline Pancreas & 63 & 46 & 59 & 34 & 25 & 56 & 72 & 87 & 74 & 81 & 74 \\
\hline Pituitary & 91 & 65 & 55 & 83 & 29 & 49 & 58 & 88 & 81 & 70 & 87 \\
\hline Placenta & 38 & 49 & 69 & 35 & 58 & 66 & 61 & 83 & 73 & 73 & 70 \\
\hline Prostate & 52 & 50 & 69 & 38 & 52 & 68 & 54 & 86 & 75 & 71 & 79 \\
\hline Salivary gland & 57 & 43 & 57 & 46 & 38 & 71 & 50 & 89 & 80 & 82 & 73 \\
\hline Skin & 75 & 33 & 49 & 57 & 35 & 77 & 72 & 91 & 59 & 76 & 84 \\
\hline Testis & 52 & 62 & 71 & 47 & 14 & 62 & 61 & 89 & 64 & 74 & 70 \\
\hline Thymus & 47 & 41 & 72 & 45 & 61 & 74 & 62 & 86 & 88 & 88 & 70 \\
\hline Thyroid & 49 & 42 & 75 & 36 & 80 & 70 & 63 & 89 & 85 & 79 & 83 \\
\hline Trachea & 64 & 35 & 65 & 45 & 63 & 70 & 64 & 87 & 84 & 83 & 79 \\
\hline Uterus & 71 & 55 & 60 & 47 & 81 & 82 & 65 & 82 & 72 & 77 & 82 \\
\hline
\end{tabular}

Data are presented as the mean values of the dynamin gene expression percentatges calculated from the individual values of the samples common to both NCBI-GEO records (GDS596 and GDS1096). The GPL96 Affymetrix probe set ID is displayed in parentheses below the gene symbol. Where there is more than one entry for the same gene, we selected the entry for which the Affymetrix probe set ID refers to the mRNA or coding DNA sequence (cds). The CNS tissues and organs are shown in the top block of the table. DNM1 and DNM3 gene expression values are shown in bold. See the legend of Figure 1. 
nervous system (CNS) (Figure 2). This data mining analysis allowed us characterise dymanin gene expression trends in the CNS. We found clear evidence that the classical dynamin DNM1 and DNM3 genes reach their maximum expression level (100\% measurement score) in all of the normal human CNS tissues studied. Moreover, this results is in contrast to the expressionprofiles observed in the other normal human organs and tissues studied, in which both the dynamin DNM1 and DNM3 genes showed approximately $50 \%$. A detailed breakdown of the data is presented in Table 1. To improve the rigor of our analysis, we used the BioGPS gene expression portal $[7,8]$ to explore the expression profiles of human dynamin-retaled genes. We found that the classical dynamin DNM1 and DNM3 genes are also maximally expressed in normal human CNS components and at significantly lower level in others organs or tissues $[9,10]$.

The CNS consists of the brain and spinal cord, where synapses are the dynamic structures through which all nervous system signals traverse. Dynamin polymerisation in membrane fission is thought to play a significant role in the synapse (Gene Ontology GO:0003373) which is suggestive of the concept of a relationship between synapses and dynamins [11]. Several animal model studies have shown that dynamin genes are highly expressed in neurons [12-15]. In conclusion, based on their high levels of expression in human CNS, DNM1 and DNM3 can be considered as CNS-specific dynamin genes, at least in the following human CNS components: amygdala, foetal brain, whole brain, caudate nucleus, cerebellum, cerebellum peduncles, cingulate cortex, globus pallidus, hippocampus, hypothalamus, medulla oblongata, occipital lobe, parietal lobe, pineal day, pineal night, pons, prefrontal cortex, spinal cord, subthalamic nucleus, temporal lobe, and thalamus. We suggest that the role of dynamins in the CNS could be a potentially interesting area for further biochemical research in neurodegenerative diseases.

\section{Competing interests}

The authors declare that they have no competing interests.

\section{Authors' contributions}

AR carried out the downloading of gene expression data from the NCBI-GEO database, helped design the study, and contributed to writing the manuscript LA wrote the manuscript and helped design the study. Both authors read and approved the final manuscript.

\section{Acknowledgements}

This study was supported by a grant from the "Ministerio de Economia y Competitivdad" of the Spanish Government (AGL 2008-00387/ALI).

Received: 28 December 2013 Accepted: 24 March 2014

Published: 28 March 2014

\section{References}

1. Praefcke GJK, McMahon HT: The dynamin superfamily: universal membrane tubulation and fission molecules? Nature Rev Mol Cell Biol 2004, 5:133-147.

2. Dynamin Hope Page. http://www.endocytosis.org/Dynamin/.
3. Hinshaw JE, Schmid SL: Dynamin self-assembles into rings suggesting a mechanism for coated vesicle budding. Nature 1995, 374:190-192

4. Sever S, Chang J, Gu C: Dynamin rings: not just for fission. Traffic 2013, 14:1194-1199. doi:10.1111/tra.12116

5. Su Al, Wiltshire T, Batalov S, Lapp H, Ching KA, Block D, Zhang J, Soden R, Hayakawa M, Kreiman G, Cooke MP, Walker JR, Hogenesch JB: A gene atlas of the mouse and human protein-encoding transcriptomes. Proc Natl Acad Sci U S A 2004, 101:6062-6067.

6. Ge X, Yamamoto S, Tsutsumi S, Midorikawa Y, Ihara S, Wang SM, Aburatani H: Interpreting expression profiles of cancers by genome-wide survey of breadth of expression in normal tissues. Genomics 2005, 86:127-141.

7. Wu C, Orozco C, Boyer J, Leglise M, Goodale J, Batalov S, Hodge CL, Haase J, Janes J, Huss JW 3rd, Su Al: BioGPS: an extensible and customizable portal for querying and organizing gene annotation resources. Genome Biol 2009, 10:R130.

8. Wu C, MacLeod I, Su Al: BioGPS and MyGene.info: organizing online, gene-entric information. Nucl Acids Res 2013, 41(D1):D561-D565.

9. DNM1 default BioGPS gene report. http://biogps.org/\#goto=genereport\&id=1759.

10. DNM3 default BioGPS gene report. http://biogps.org/\#goto=genereport\&id=26052.

11. Watanabe S, Rost BR, Camacho-Pérez M, Davis MW, Söhl-Kielczynski B, Rosenmund C, Jorgensen EM: Ultrafast endocytosis at mouse hippocampal synapses. Nature 2013, 504:242-247. doi:10.1038/nature12809.

12. Cook T, Mesa K, Urrutia RJ: Three dynamin-encoding genes are differentially expressed in developing rat brain. J Neurochem 1996, 67:927-931.

13. Gray NW, Fourgeaud L, Huang B, Chen J, Cao H, Oswald BJ, Hemar A, McNiven MA: Dynamin 3 is a component of the postsynapse, where it interacts with mGluR5 and Homer. Curr Biol 2003, 13:510-515.

14. Ferguson SM, Brasnjo G, Hayashi M, Wolfel M, Collesi C, Giovedi S, Raimondi A, Gong LW, Ariel P, Paradise S, OToole E, Flavell R, Cremona O, Miesenböck G, Ryan TA, De Camilli P: A selective activity-dependent requirement for dynamin 1 in synaptic vesicle endocytosis. Science 2007, 316:570-574.

15. Raimondi A, Ferguson SM, Lou X, Armbruster M, Paradise S, Giovedi S, Messa M, Kono N, Takasaki J, Cappello V, OToole E, Ryan TA, De Camilli P: Overlapping role of dynamin isoforms in synaptic vesicle endocytosis. Neuron 2011, 70:1100-1114.

doi:10.1186/1756-0500-7-188

Cite this article as: Romeu and Arola: Classical dynamin DNM1 and DNM3 genes attain maximum expression in the normal human central nervous system. BMC Research Notes 2014 7:188.

\section{Submit your next manuscript to BioMed Central and take full advantage of:}

- Convenient online submission

- Thorough peer review

- No space constraints or color figure charges

- Immediate publication on acceptance

- Inclusion in PubMed, CAS, Scopus and Google Scholar

- Research which is freely available for redistribution 